\title{
IJPHN
}

\section{An Effective Method to Predict Low Birth Weight in Indonesia Rural Area}

\author{
Asyifa Robiatul Adawiyah ${ }^{1}$, Kusharisupeni Djokosujono2*, Nur Alam ${ }^{3}$, Novita Arie Setiawati ${ }^{4}$ \\ ${ }^{1}$ Department of Public Health, Faculty of Health Science Universitas Respati Indonesia \\ ${ }^{2}$ Department of Public Health Nutrition Faculty of Public Health Universitas Indonesia, F Building $2^{\text {nd }}$ \\ Floor Kampus Baru UI Depok 16424, Indonesia \\ ${ }^{3}$ Study Program of Bachelor of Midwifery, Faculty of Health, Universitas Muhammad Thamrin Indonesia \\ ${ }^{4}$ Department of Public Health Nutrition Faculty of Public Health Universitas Indonesia, F Building $2^{\text {nd }}$ \\ Floor Kampus Baru UI Depok 16424, Indonesia
}

*Corresponding Author:

Kusharisupeni Djokosujono

E-mail: kusharisupeni@gmail.com

\begin{abstract}
Antenatal care (ANC) is a compulsory program in Indonesia with minimally 4 times visits, unfortunately, regular Antenatal care visit at Kanjillo health center, South Sulawesi, Indonesia is still low. Most of the Low Birth Weight (LBW) cases in Indonesia happened in a rural-areas, where most of the women conducted the first visit ANC on the third trimester. This study aimed to determine the cut-off point of mother's last trimester pregnancy weight for predicting as well as preventing low birthweight outcomes in the community. The research design was cross-sectional with secondary data taken from the Kanjilo health center, with 150 pregnant mothers visited the health center in 2019, as samples. Anthropometric measurements were used to determine the pregnancy weight in the last trimester as well as the weight of the baby born. Univariate, bivariate, multivariate analysis as well as Receiving Operation Characteristic (ROC) analysis was used. Cut off point of $60.5 \mathrm{~kg}$ of pregnancy weight in the third trimester of pregnancy and 0.919 AUC can predict low birth weight. To confirm this method, validation should be done in the community setting in several rural areas.
\end{abstract}

Key words: Antenatal care, Low birth weight, Rural area

\begin{abstract}
Abstrak
Antenatal Care (ANC) merupakan program wajib di Indonesia dengan kunjungan minimal 4 kali, sayangnya kunjungan ANC rutin di Puskesmas Kanjillo, Sulawesi Selatan, Indonesia masih rendah. Sebagian besar Berat Bayi Lahir Rendah (BBLR) di Indonesia lahir di daerah pedesaan, dimana sebagian besar ibu melakukan kunjungan ANC pertama kalinya pada trimester ketiga. Penelitian ini bertujuan untuk menentukan titik potong berat badan ibu hamil trimester terakhir untuk memprediksi serta mencegah hasil BBLR di masyarakat. Desain penelitian menggunakan cross sectional dengan data sekunder diambil dari Puskesmas Kanjilo, dengan jumlah sampel 150 ibu hamil yang berkunjung ke Puskesmas pada tahun 2019. Pengukuran antropometri digunakan untuk mengetahui berat badan kehamilan pada trimester terakhir serta berat badan bayi yang dilahirkan. Analisis yang digunakan adalah univariat, bivariat, multivariat serta analisis Receiving Operation Characteristic (ROC). Titik potong berat badan kehamilan pada trimester ketiga kehamilan didapatkan 60,5 $\mathrm{kg}$ dan 0,919 pada Area Under Curve (AUC) dapat memprediksi berat badan lahir rendah. Untuk mengkonfirmasi metode ini, validasi harus dilakukan di lingkungan masyarakat di beberapa daerah pedesaan.
\end{abstract}

Kata kunci:Kunjungan Antenatal, Berat badan lahir rendah, Daerah pedesaan 


\section{Introduction}

Many studies about anthropometric had been carried out, but still no agreement on how to detect pregnant women with acute malnutrition, through which we can enroll them in a nutrition program as soon as possible. This suggestion is of most importance as pregnant women with acute malnutrition associated with low birth weight, and adverse birth outcome. Many studies agreed that MUAC is a suitable indicator of risk of having low birth weight. MUAC is an anthropometric measurement that needs more accuracy and usually is conducted in the early first trimester of pregnancy.

Low birth weight is still a public health problem in developing countries. With its high risk in growth and development, low birth weight should be prevented. Early third trimester of pregnancy is the period where mothers, especially those in rural areas (1), usually visit antenatal care. As in this period, rapid pregnancy weight gain still occurs nutritional program could still be implemented to combat low birth weight.

The global prevalence of low birth weight (LBW) is still high (15.5\%) where most of them $(96.5 \%)$ are living in developing countries (2). This prevalence of low birth weight is responsible for $60-80 \%$ of world neonatal death. Although In Indonesia the prevalence of LBW is considered low, it is steadily increasing should be considered: in $20075.4 \%$; 5.7\% in 2013, to $6.2 \%$ in $2018(3,4)$.

Ante-Natal Care (ANC) is a compulsory program in Indonesia with minimally 4 times visits (5). The aim among others preventing adverse birth outcomes, low birth weight. Unfortunately, ANC visit is still low. Data from RISKESDAS (Indonesia Basic Health Research) showed that the percentage for $\mathrm{K} 1$ (first-trimester antenatal visit) was ranging from $66.8 \%$ in Papua to $98.8 \%$ in Central Java (4). While the percentage for K4 (last trimester antenatal visit) is $74.1 \%$ nationally, ranging from Papua $43.8 \%$ to $90.2 \%$ in DI Yogyakarta (4). In Indonesia, most of low birth weight occurred in rural areas, where most of pregnant women visit antenatal care only in their third trimester of pregnancy. Several studies showed that the first, second as well as third trimester of pregnancy could be used to predict birth weight and most of them had been carried out in clinical settings (6-8) with different results.

Velankar showed that evidence of low birth weight increased among mothers who visited first Ante-Natal care in the late trimester of pregnancy (9). About $50.7 \%$ of pregnant mothers who visiting first Ante-Natal care more than the age of 29 weeks of pregnancy increase risk for having low birth weight. The above study result was shown also in Nigeria (10). Another study showed that those pregnant mothers who visited Ante-Natal Care in the second as well as in the third trimester had a higher risk of having low birth weight (11).

Studies predicting birth weight through the early third trimester weight of pregnancy are very few, especially in a community setting. Kusharisupeni, Putra, Utari, and Fajarini in their study in a clinic in an urban area found $59.8 \mathrm{~kg}$ as the optimum pregnancy weight in the third trimester to determine low birthweight (12). The clinical setting is different compared to a community setting. While in the clinical setting those mothers who visit ANC usually come from middle to high socio-economic groups, in the community most of those who visit antenatal care in health centers are mothers from the low socialeconomic groups. As in rural community in Indonesia, most of 
pregnant women visit antenatal care in the third trimester of pregnancy, therefore this study result may provide a better understanding that visiting antenatal care earlier in trimester and regularly will decrease low birth weight. But still in a situation where many pregnant mothers visiting antenatal care in early third trimester, a cut-off point of predicted birth weight should be determined, wherein this last trimester of pregnancy promoting nutritional status to prevent low birth weight could still be implemented though in a short period as well as good preparation care for those low birth weight babies.

This study aims to determine the optimum cut-off point of mother's last trimester pregnancy weight for preventing low birth weight outcomes in the community.

\section{Methods}

This study was conducted in a remote area, Kanjilo Health center which is located at Barombong subdistrict, district of Gowa, West Sulawesi, Indonesia. Most of the mothers who visited antenatal care belong to the low socio-economic groups. The research design was cross-sectional with secondary data of the above Puskesmas. Permission was obtained from the head of Puskesmas Kanjilo (Kanjilo Health center) Samples are all pregnant mothers who visited this health center in the year 2019 as many as 150 mothers.

Data were collected from the medical report of Kanjilo health center: age of the mother, age of the pregnancy, antenatal visit, weight of mother in the midlle of trimester pregnancy, and birth weight of the baby.

Age of pregnancy was predicted based on the date of the last menstrual Period by Naeggle (13). The weight of the pregnant mothers was measured with seca scale in $\mathrm{kg}$ and birth weight of the outcome with baby's scale in gram. All mothers terminated their pregnancy for more than 37 weeks.

Univariate analysis was used to describe the characteristic of the samples, bivariate and multivariate analysis to determine the relationship between the dependent and independent variables and to decide the determinant factor of the above relationship as well. Receiving Operation Characteristic (ROC) analysis was used to determine the ability of the score to classify or to predict the condition (low birth weight or normal weight). The analysis may also be used to determine the optimal cut-off point (optimal decision threshold). To know whether this cut off point is accurate we also analyze the area under the curve. The accuracy of the test depends on how well the test separates the group being tested into those with low birth weight and normal weight. Accuracy is measured by the area under curve, the ROC curve. An area of 1 represents a perfect test; an area of 0.5 represents a worthless test. A rough guide for classifying the accuracy of a diagnostic test is the traditional academic point system: $0.90-1=$ excellent (A); $0.80-0.90=\operatorname{good}(\mathrm{B}) ; 0.70-0.80=$ fair (C); $0.60-0.70=$ poor (D) and $0.50-0.60$ $=$ fail $(\mathrm{F})(14)$.

\section{Results}

In this study, all mothers have aterm delivery (more than 37 weeks of pregnancy). Mean of the mother's weight in the third trimester was 63.65 $\mathrm{kg}$, with low birth weight $32.7 \%$, 38\% pregnant mothers have low nutritional status, suffering from anemia 54\%, suffering from hypertension $60 \%$. Other characteristics are $81.3 \%$ with low education, no job 70\%, and unfortunately, antenatal care visit less than 4 times $62.4 \%$ (Table 1).

All independent variables show a significant relationship with low birth 
weight (Table 2). Further analysis (multivariate analysis) shows that factors relate significantly to birthweight are mother's pregnancy weight and mother's age, with trimester pregnancy weight as the dominant factor (Table 3).

From Table 4 and Figure 1 we can observe that the AUC (area under curve) was $0.919(0.878-0.960)$ with a cut-off point $60.5 \mathrm{~kg}$, sensitivity $95.9 \%$, specificity $76.2 \%$, PPV $66.19 \%$ and
NPV $97.46 \%$. With cut-off point $60.5 \mathrm{~kg}$ for mother's pregnancy weight in third trimester, we can expect that (table 4) $47 / 150 \times 100 \%=31.3 \%$ of babies are low birth weight $(<2500$ grams). AUC was found 0.919 which means that the accuracy of a diagnostic test is Excellent (0.90-1). Cut-off above would be "excellent" separating low birth weight from normal weight.

Table 1. Characteristics of Respondents

\begin{tabular}{lcc}
\hline Variables & Mean \pm SD & Min-Max \\
\hline Birth weight (gram) & 2795.67 & $1350-3900$ \\
Maternal age (year) & $26.75 \pm 5.222$ & $16-36$ \\
Length of gestation (month) & 37.08 & $35-40$ \\
Parity & 2.58 & $1-8$ \\
Mother's early third-trimester weight $(\mathrm{kg})$ & $63.65 \pm 5.618$ & $55-75$ \\
\hline
\end{tabular}

Table 2. Distribution of Variables

\begin{tabular}{lcc}
\hline Variables & $\mathbf{n}$ & $\mathbf{\%}$ \\
\hline ANC Visit & & \\
$\quad<4$ times & 94 & 62.7 \\
$\quad \geq 4$ times & 56 & 37.3 \\
Birth Weight & & \\
$\quad$ Low birth weight < 2500 gram & 49 & 32.7 \\
$\quad$ Normal ( 2500 gram & 101 & 67.3 \\
Nutritional status (Body Mass Index) & & \\
$\quad<23,5$ & 57 & 38.0 \\
$\quad \geq 23.5$ & 93 & 62.0 \\
Anemia during pregnancy & & \\
$\quad$ H $11 \%$ & 81 & 54.0 \\
$\quad$ Hb $\geq 11 \%$ & 69 & 46.0 \\
Hypertension & & \\
$\quad \geq 140 / 90$ mm Hg & 90 & 60.0 \\
$\quad<140 / 90$ & 60 & 40.0 \\
Education & & \\
$\quad$ Low & 122 & 81.3 \\
$\quad$ High & 26 & 18.7 \\
Occupation & & \\
$\quad$ Yes & 45 & 30.0 \\
$\quad$ No & 105 & 70.0 \\
\hline
\end{tabular}

Table 3. Final Model for Determinant Factor

\begin{tabular}{lcc}
\hline Variables & p-value & OR 95\% CI \\
\hline Pregnancy Weight & 0.000 & $3.874(1.917-7.826)$ \\
Maternal Age & 0.001 & 0.093 \\
Anemia & 0.178 & 0.421 \\
\hline
\end{tabular}


Table 4. ROC Curve

\begin{tabular}{ll}
\hline AUC & $0.919(0.878-0.960)$ \\
Cut off & 60.50 \\
Sensitivity & $95.9 \%$ \\
PPV & $66.19 \%$ \\
NPV & $97.46 \%$ \\
\hline
\end{tabular}

\section{ROC Curve}

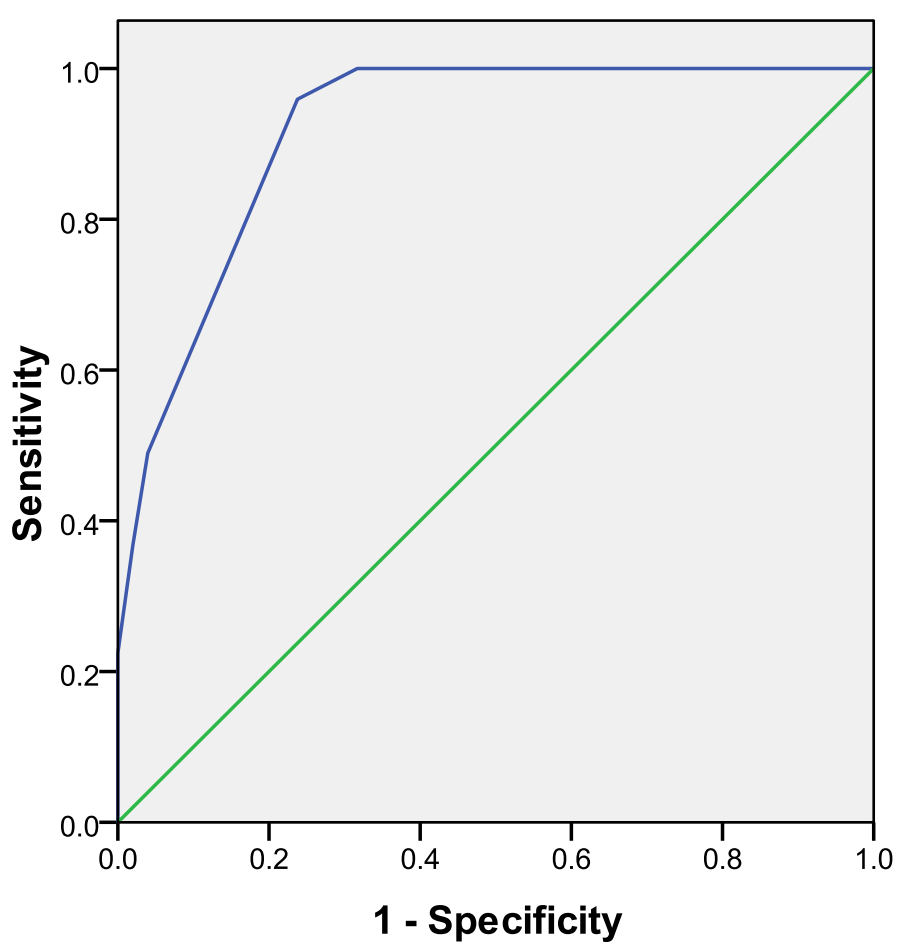

Diagonal segments are produced by ties.

Figure 1. ROC Curve of Low Birth Weight

\section{Discussion}

The definition of low birthweight by WHO $(<2500$ gram $)$ emphasizes the importance of birth weight as an important variable in relation to perinatal outcome (15). Low birthweight is still a public health problem in Indonesia, especially in rural areas Indonesia $6.8 \%$ (3); urban $6.6 \%$ and rural $7 \%$ (16). The majority of this problem was caused by low frequency of antenatal care. AnteNatal Care (ANC) is a compulsory program in Indonesia with minimally 4 times visits (5), but unfortunately, most of the pregnant mothers visited antenatal care only once usually during the first trimester, due to many factors. Indonesia Demographic and Health Survey 2017 shows that Indonesian antenatal care during the third trimester is poor, the first trimester $84 \%$, second trimester $14.3 \%$ and third trimester $1.7 \%$ (16). In the urban area of Indonesia, first trimester $86.9 \%$, second trimester $11.8 \%$ and last trimester $1.3 \%$, while in a rural area first trimester $80.9 \%$, second trimester $19.1 \%$ 
and last trimester $2.2 \%$. As the number of visiting antenatal care during the third trimester is very small, so it is important to know whether the baby will bear normal weight or low birth weight to anticipate the risk of low birthweight. Our study revealed that antenatal visit less than 4 times is $62.7 \%$, a number which needs high attention. Low birth weight $32.7 \%$ in this study area is higher than Indonesia data.

Birth weight is a reflection of weight gain in the latter part of pregnancy specially and the adequacy of energy intake in that period (17). The rule of Indonesian ANC visit program is 1,1,2, which means that in the first trimester pregnant mother should visit one time for antenatal care, second trimester one while third trimester twice. This program shows the importance of last trimester visit.

Based on the study result, it reveals that the majority of the pregnant mothers in this area study may have a high risk for having low birth weight babies. Besides, the risk could be higher as $62.4 \%$ of them visited antenatal care less than 4 times, especially during the early period of the third trimester. Multivariate analysis showed that the dominant factor for having low birth weight in this study is pregnancy weight in the last trimester.

The aim of this study is, in a situation where many pregnant mothers visiting antenatal care only in the early third trimester (as this is happens in most rural Indonesia), cut-off point for predicting birth weight based on last trimester pregnancy weight should be determined. This is important to set a peak birthweight of neonates that happens in the last trimester (12) whether a normal or low birth weight baby will be born. This study revealed that pregnancy weight in the third trimester could be used to predict low birth weight. Based on the cut-off point we analyzed in this study (60.5 kg), $32.7 \%$ babies were born LBW. This finding confirmed the prevalence of LBW as reported in Kanjillo village (31.3\%). Another study with the same methodology but carried out in a clinic in an urban area (12) showed that the cut-off point for predicting low birth weight based on the third trimester pregnancy weight was $59.8 \mathrm{~kg}$.

Analysis based on the pre pregnany weight up to pregnancy weight gain at the end of trimester normally around 60 $\mathrm{kg}$ (45 kg for pregnancy weight and 12 $\mathrm{kg}$ for pregnancy weight gain) (18). And this number confirms the study's cut-off point in this study. Pre pregnany weight as well as weight gain data are something that rarely available in rural areas, so this cut-off point found in this study is worth to using.

The area under curve and ROC curve (AUC) is generally a measure for detecting the accuracy of a diagnostic test. It was found that a higher AUC value indicate better test performance. It ranges from 0.5 (no diagnosis ability) to 1.0 (perfect diagnosis ability). A rough guide for classifying the accuracy of a diagnostic test is the traditional academic point system: $0.90-1=$ excellent (A) ; $0.80-0.90=\operatorname{good}(\mathrm{B}) ; 0.70-0.80=$ fair (C); $0.60-0.70=$ poor (D) and 0.50 $0.60=$ fail $(\mathrm{F})(14)$. With 0.919 AUC found in this study, the above cut-off point has a perfect diagnosis ability.

\section{Conclusion}

In conclusion, cut-off point 60.5 $\mathrm{kg}$ of pregnancy weight in the third trimester of pregnancy is able to predict low birth weight. As the majority of low birth weight in Indonesia are found in a rural community as well a quite number of pregnant mothers visit antenatal care only at the third trimester, thus to confirm this new method to detect low 
birthweight, validation should be carried out in a community setting in several rural areas.

\section{Acknowledgment}

We thank The Head of Puskesmas Kanjillo, Humaira Saimima, S.ST, M.Kes for the data of Kanjillo.

\section{References}

1. Mahumud RA, Sultana M, Sarker AR. Distribution and determinants of low birth weight in developing countries. J Prev Med Public Heal. 2017;50(1):18-28.

2. World Health Organization. Care of the preterm and low-birthweight newborn World Prematurity Day - 17 November 2018 [Internet]. 2020 [cited 2020 Dec 15]. Available from: https://www.who.int/maternal_chi ld_adolescent/newborns/prematuri ty/en/

3. Badan Penelitian dan Pengembangan Kesehatan. Riset Kesehatan Dasar (RISKESDAS) 2013. Lap Nas 2013. 2013;

4. Badan Penelitian dan Pengembangan Kesehatan. Laporan Nasional Riset Kesehatan Dasar 2018. 2018.

5. Kementerian Kesehatan RI. Buku Saku Bagi Bidan/Perawt dan Kader Kesehatan Untuk Mendukung Pengembangan Desea dan Kelurahan Siaga Aktif. 2014; Available from: http://promkes.depkes.go.id/wpcontent/uploads/pdf/buku_pedoma n/Buku Saku Kader Desa Siaga.pdf

6. Lumbanraja S, Lutan D, Usman I. Maternal Weight Gain and Correlation with Birth Weight
Infants. Procedia - Soc Behav Sci [Internet]. 2013;103:647-56. Available from: http://dx.doi.org/10.1016/j.sbspro. 2013.10.383

7. Pressman EK, Bienstock JL, Blakemore KJ, Martin SA, Nancy A C. Prediction of birth weight by ultrasound in the third trimester. Obstet Gynecol. 2000;95(4):5026.

8. Ismail KS, Mahgoub AA, Kunna A, Elkheir HA, Mohamed SE, Taha U. Estimation of placenta thickness in third trimester to determine fetal weight in Sudanese women 2016. 2017;1(2):2016-8. Available from: http://www.alliedacademies.org/

9. Velankar DH. Maternal Factors Contributing to Low Birth Weight Babies in an Urban Slum Community of Greater Mumbai. BOmbay Hosp J. 2009;51(1):2635.

10. Oladeinde $\mathrm{HB}$, Oladeinde $\mathrm{OB}$, Omoregie R, Onifade AA. Prevalence and determinants of low birth weight: The situation in a traditional birth home in Benin city, Nigeria. Afr Health Sci. 2015;15(4):1123-9.

11. Bhaskar RK, Deo KK, Neupane U, Chaudhary Bhaskar S, Yadav BK, Pokharel HP, et al. A Case Control Study on Risk Factors Associated with Low Birth Weight Babies in Eastern Nepal. Int $\mathbf{J}$ Pediatr. 2015;2015:1-7.

12. Djokosujono K, Putra WKY, Utari DM, Fajarini IA. Prediction of Low Birth Weight Based on Maternal Third Trimester Weight Among Mothers at a Maternal Clinic in Jakarta, Indonesia. Media Gizi 
Indones. 2021;16(2).

13. Lawson GW. Naegele's rule and the length of pregnancy - A review. Aust New Zeal J Obstet Gynaecol. 2020;1-6.

14. Ekelund S. ROC curves - what are they and how are they used? [Internet]. 2011 [cited 2021 Feb 8]. Available from: https://acutecaretesting.org/en/arti cles/roc-curves-what-are-theyand-how-are-they-used

15. FALKNER F, STEIGMAN AJ, CRUISE MO. The physical development of the premature infant. I. Some standards and certain relationships to caloric intake. J Pediatr. 1962 Jun 1;60(6):895-906.

16. Badan Pusat Statistik. Survei Demografi dan Kesehatan 2017. Ris Kesehat Dasar 2018. 2018;1446.

17. Lagiou P, Tamimi RM, Mucci LA, Adami HO, Hsieh CC, Trichopoulos D. Diet during pregnancy in relation to maternal weight gain and birth size. Eur $\mathbf{J}$ Clin Nutr. 2004 Feb;58(2):231-7.

18. Human energy requirements [Internet]. [cited 2021 Mar 6]. Available from: http://www.fao.org/3/y5686e/y568 6e0a.htm 